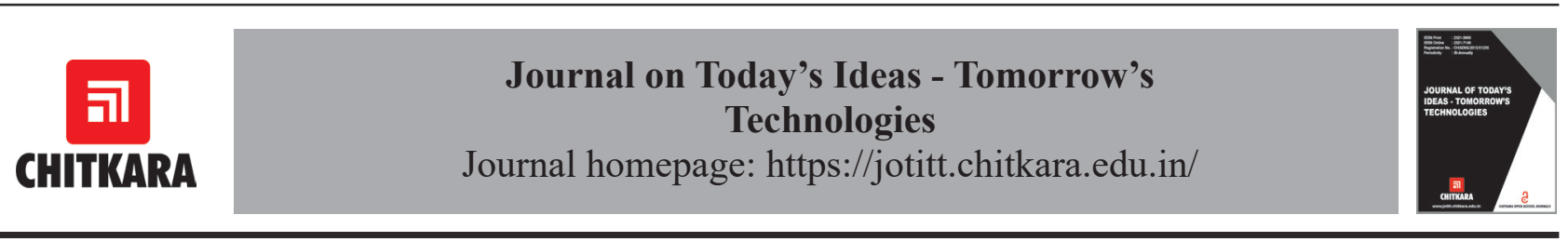

\title{
Effect of Bacteria Inoculums on Compressive Strength
}

\author{
Prakash Mallappa Munnoli ${ }^{*}$, Sudisha Jogayya ${ }^{2}$, Jyoti Gupta ${ }^{1}$, Geeta Shetteppanavar ${ }^{1}$, \\ Pooja Bandekar ${ }^{1}$ and Sandhay Basavaraj ${ }^{1}$

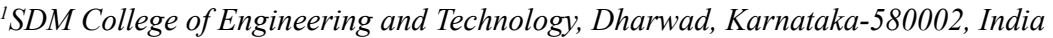 \\ ${ }^{2}$ Department of Biotechnology and Microbiology, KUD Dharwad, Karnataka-580003, India
}

*munnolipm@gmail.com (Corresponding Author)

\section{ARTICLE INFORMATION}

Received: June 04, 2020

Revised: September 25, 2020

Accepted: September 29, 2020

Published Online: June 22, 2021

Keywords:

Calcite precipitation,

Bio-deposition, Compressive

strength, Bacillus Subtilis,

Bacillus Pumilis, Pseudomonas

Fluorescence

DOI: $10.15415 /$ jotitt.2020.82008

\begin{abstract}
The use of bio-concrete is increasing in the present day context and researchers are working on strength and durability characteristics of concrete using bacteria species which have shown calcite precipitation. Three different species of bacteria namely P. Fluorescence, B. Pumilis and B. Subliis that have calcite precipitation properties have been investigated in this study. The investigations were carried first on cement mortar (CM) cubes using these three bacteria species suspension of $20 \% ; 40 \%$ and $60 \%$ having colony forming units P. Fluorescence $\left(10^{8} \mathrm{CFU} / \mathrm{ml}\right)$, B. Pumilis $\left(10^{6} \mathrm{CFU} / \mathrm{ml}\right)$ and B. Subtilis $\left(10^{8}\right.$ $\mathrm{CFU} / \mathrm{ml}$ ) respectively. The $40 \%$ suspension in all the three cases has shown increased compressive strength as compared to $20 \%$ and $60 \%$. The compressive strength measured showed increase (CS) of $18 \% ; 12 \%$ for P. Fluorescence; B. Subtilis and decrease of $35 \%$ with B. Pumilis respectively. B. Subtilis with optimized $40 \%$ suspension having $\mathrm{CFU} 10 \times 10^{8} / \mathrm{ml}$ showed $4.32 \% ; 5.56 \%$; and $3.81 \%$ increase in CS of CC cubes with 3 days; 7 days and 28 days respectively and $5.92 \%$ overall increase in $\mathrm{CS}$ of $\mathrm{CC}$ cubes as compared to the 3 days CS of control cube.
\end{abstract}

\section{ABBREVIATIONS}

SDW: Sterile Distilled Water; SHC: Self-Healing Concrete; PCR: Polymerase Chain Reaction; BC: Bacterial Concrete; CP: Calcite precipitation; CS: Compressive Strength; CC: Cement Concrete; CM: Cement Mortar; MTCC: Microbial Type Culture Collection; CFU: Colony Forming Unit/ml

\section{Introduction}

The concrete is the modern material used globally to fulfill the needs of infrastructure development. The research on this material is as old as the invention of cement itself. The maintenance of concrete structures is of significance to have a long structural life [1]. Therefore, CS and durability studies are important in the shelf-life of concrete.

Bacteria Concrete can be made by embedding bacteria in the concrete that are able to constantly precipitate calcite [Q]. This phenomenon is called microbe (bacteria) induced calcite precipitation [3-4] These bacteria are able to produce extracellular urease enzymes. The hydrolysis of urea to carbon dioxide and ammonia can be catalyzed by urease enzyme. The hydrolyzed ammonia and carbon dioxide increases the $\mathrm{pH}$ and carbonate concentration in the bacterial environment, respectively $[5,6]$. Based on the calcite precipitation of bacterial several researchers have employed various bacteria species for the CS studies $B$. Thermusthermophilus [7]; B. Pasteurii [8]; Escherichia Coli [8]; Pseudomonas Aeruginosa [8]; B. Flexes [9] B. Sphaericus $[10,11,12]$; B. Cereus [13]; B. Cohni, E. Coli [14]; B. Subtilis [3, 7, 10, 14, 15-18]; Bacillus Sphaericus, Bacillus Pasteurii $[10,12,13]$.

Micro-cracks are the main cause to the ingress of moisture and deterioration leading to structural failure [1-19]. It has been reported in literature that mineralproducing bacteria could be used for sand consolidation 
as well as for the repair of limestone monuments [20, 21, 22]. The pores and crack filling were extensively studied for the maintenance; leakages and durability point of view [23, 24]. The strain B. Subtilis was used by many researches in the formation of calcium silicate hydrated gel by means of adsorbing silicate using chemically modified B. Subtilis (CMBS) [25, 8]. The Reports say $28 \%$ improvement in the CS of CMBS incorporated concrete compared to control concrete with optimum concentration of $10^{6}$ cells $/ \mathrm{ml}$. The 7 day, 14 day and 28 days CS, was carried out using portland cement with mortar cubes and concrete cubes with cell concentration of E.Coli from $10^{1}$ to $10^{7}$ when compared with control (without E.Coli) did not show any change [8].

Similarly B. Subtilis showed no improvement in CS when used with concentration of $10^{5}[3]$. However, inoculation with B. Sphaericus result in increase of CS as well as improvement of split tensile test strength. It has been reported that CS has increased by $30.76 \%, 46.15 \%$, and $32.21 \%$ respectively on Day 3, 7 and 28 respectively with B. Sphaericus inoculation, and during the same period split tensile test strength has been increased by $13.75 \%, 14.28 \%$ and $18.35 \%$ respectively [26]. The increase in 28 days CS, Split Tensile Strength, Flexural Strength are 16.18; 17.74; $14.42 ; 13.75 ; 30.56 ; 26.51 \%$ when inoculated with B. Subtilis for M20 \& M40 Grade respectively [27]. The increase in CS at 7 and 28 days were found to be $28.53 \%$ and $17.21 \%$, using Spirulina and $33.99 \%$ and $24.67 \%$, using B. Subtilis respectively, when compared to control concrete without bacteria [28, 29]. The literature review shows that there is a further scope to work in the direction of obtaining durable concrete using bacteria inoculation by conducting pin pointing experiments using different bacteria species which are known to precipitate calcite.

\section{Materials and Methods}

\subsection{Isolation and Classification of Strains}

The isolation and maintenance of pure culture for the selected bacterial species B. Subtilis, P. Fluorescence, B. Pumilis by dilution pour plate method as per the standard procedures outlined [29, 17, 30] and were regularly subcultures at regular interval for the purity and maintained at the department of Biotechnology KUD Dharwad.

\subsection{Bacterial Species}

B. Subtilis, P. Fluorescence, B. Pumilis are used which were procured from Department of biotechnology and microbiology KUD, Dharwad. The bacterial species in suspension was brought to the laboratory with concentration as given in Table $1 \& 2$.
Table 1: Bacterial species in suspension

\begin{tabular}{|l|c|}
\hline Species & Concentration in CFU/ml \\
\hline B. Subtilis & $10 \times 10^{8}$ \\
\hline P. Fluorescence & $10 \times 10^{8}$ \\
\hline B. Pumilis & $10 \times 10^{6}$ \\
\hline
\end{tabular}

Table 2: Concentration of bacteria suspension and water

\begin{tabular}{|c|c|c|c|}
\hline $\begin{array}{l}\text { Concentration } \\
(\%) \text { of bacterial } \\
\text { inoculums }\end{array}$ & Total & $\begin{array}{l}\text { Quantity } \\
\text { of water } \\
\text { in } \mathrm{ml}\end{array}$ & $\begin{array}{l}\text { Bacteria Saline } \\
\text { suspension in } \mathrm{ml}\end{array}$ \\
\hline 20 & $270 \mathrm{ml}$ & 216 & $20 \%$ of $270=54$ \\
\hline 40 & $270 \mathrm{ml}$ & 162 & $40 \%$ of $270=108$ \\
\hline 60 & $270 \mathrm{ml}$ & 108 & $60 \%$ of $270=162$ \\
\hline
\end{tabular}

\subsection{Materials for Cement Mortar and Concrete}

Cement with consistency 33\%; SpGr-3.15; Coarse aggregate with SpGr-2.71; Fine aggregate Sp Gr-2.6); water were used as per IS: 4031-1988; IS: 2386-1963; IS383 zone II; IS 456 respectively.

\subsection{Cement Mortar (1:3)}

Mortar cubes $(70.6 \mathrm{~mm} \times 70.6 \mathrm{~mm} \times 70.6 \mathrm{~mm})$ were prepared as per standards specified by IS: 4031 part 6 . The compressive strength of the mortar cubes at 3 days, 7 days and 28 days was determined. Mortar cubes with and without additions of bacteria were cast.

\subsection{Concrete Cubes}

The concrete mix cubes of M25 grade were cast in accordance with IS 10262-2012 of dimensions (150*150*150) $\mathrm{mm}$ respectively. The bacteria inoculums were $40 \%$ of the total water content i.e. $300 \mathrm{ml}$. Slump test is carried out as per the procedure outlined in IS 456-2000. Similarly a slump of $75 \mathrm{~mm}$ for M30 grade concrete is recorded using B. Subtilis [7]. Curing was carried out in accordance with IS 10262:2012. CS is measured at 3, $7 \& 28$ days.

\section{Results and Discussion}

\subsection{Compressive Strength of Mortar Cubes}

The 3 day CS for CM cubes casted with P. Fluorescence showed decreasing values, where as the 7 and 28 days CS have shown increased values for all the three 20\%; $40 \%$ and $60 \%$ bacteria suspension respectively as compared to the control CM cube CS Fig. 1. The CS values for $40 \%$ and $60 \%$ suspensions have almost the same values resulting in overlapping of trends. 


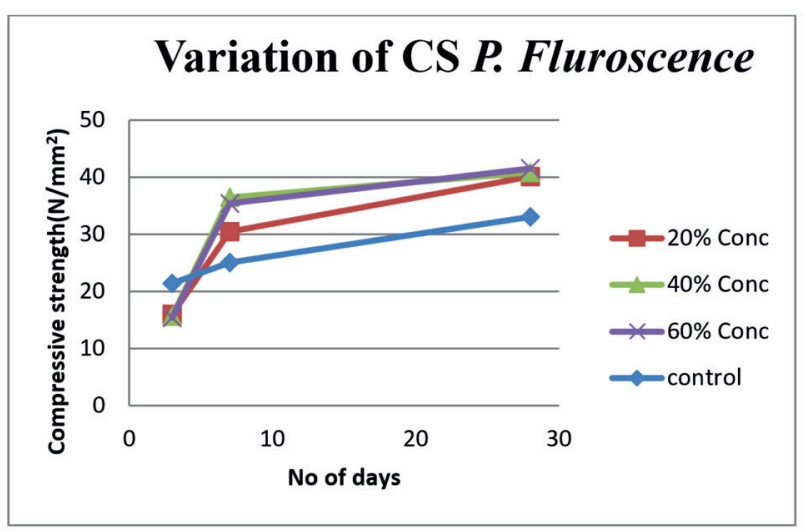

Figure 1: Variation in CS with P. Fluorescence and control

The 3, 7 and 28 days CS for CM cubes casted with $B$. Subtilis have shown increasing values as compared to the control CM cube Fig. 2. The 3, 7 and 28 days CS for CM cube casted with $B$. Pumilis have shown decreasing values as compared to control CM cube for all the 20\%, $40 \%$ and $60 \%$ bacteria suspension Fig. 3. The compressive strength measured showed increase CS of CM cubes $18 \% ; 12 \%$ for P. Fluorescence; B. Subtilis and decrease of $35 \%$ with B. Pumilis respectively.

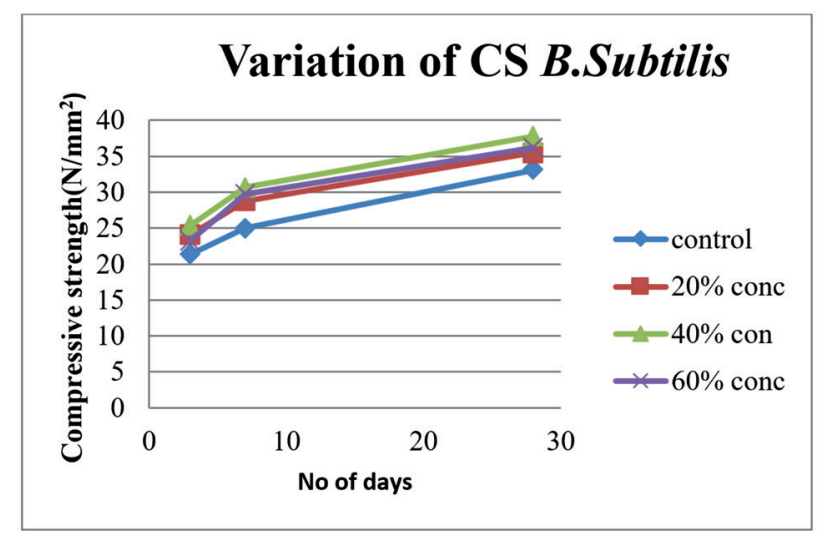

Figure 2: Variation in CS with B. Subtilis and control

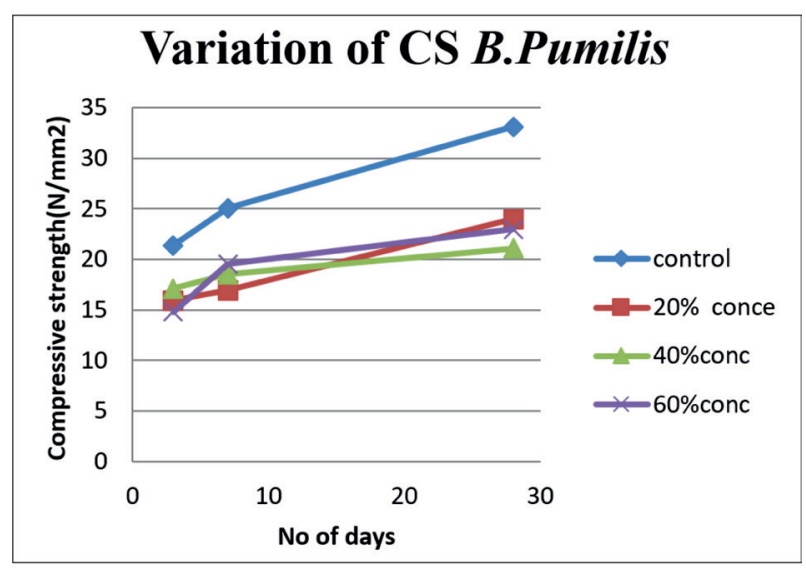

Figure 3: Variation of CS with B. Pumilis and control
The order of CS for development CM Cubes is P. Fluorescence $>$ B. Subtilis $>$ B. Pumilis. The highest CS of 28 days in the species is given by $B$. Subtilis $40 \%$ bacteria suspension. The 3 days and 7 days early strength development is better with B. Subtilis which is of significance in removal of formwork. The B. Subtilis species has shown its superiority in developing the CS in CM Cubes and therefore the compressive strength of concrete cubes is further carried out only with B. Subtilis. The available literatures of Reddy S P et al. (2012)[3] confirms our study and Seshagiri Rao et al. (2012) [18] have also shown the similar results of increasing CS of $25 \%$ in 28 days with $B$. Subtilis. The review also supports the use of B. Subtilis species [3, 7, 10, 16, 18, 23, 14, 15]. The strength improvement is due to growth of filler material within the pores of the cement-sand matrix. There is gain in strength after cooling in all grades of controlled and bacterial concretes may be due to the absorption of moisture from the surrounding medium which leads to extra hydration. The moisture content has a significant bearing on the strength of concrete. The CS increase is $18.3 \%$ and $12.2 \%$ respectively for B. Sphaericus and Sporosarcina Pastuerii. The increased CS with $B$. Subtilis strains is also reported when used in combination in fiber concrete [10].

\subsection{CS of Concrete Cubes with Bacillus Subtilis}

Depending upon the results of CS of mortar cubes with selected bacterial speciesand analyzing, high \% increase in CS is showed by B. Subtilis. Therefore, concrete cubes using B. Subtilis only are casted and subjected to CS test and the results are placed in Fig 4. The addition of $B$. Subtilis showed noticeable increase in the compressive strength of concrete B. Subtilis with optimized $40 \%$ suspension having CFU $10 \times 10^{8} / \mathrm{ml}$ showed $4.32 \%$; $5.56 \%$; and $3.81 \%$ increase in CS of CC cubes with 3 days; 7 days and 28 days respectively and $5.92 \%$ overall increase in CS of CC cubes as compared to the 3 days CS of control cube.

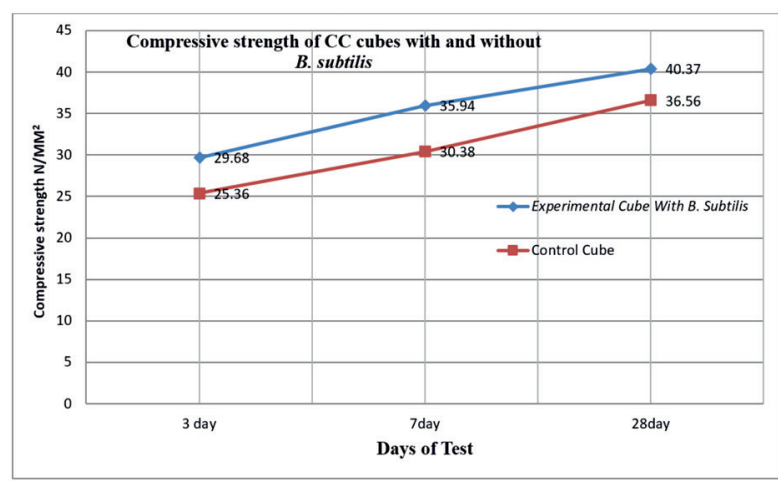

Figure 4: Variation in CS of concrete cubes with Bacillus Subtilis and control 
The increase in CS is in conformity with the results of $[16,24]$. However the studies in bio concrete are at the infant stage requiring more pin pointing experiments to solve the field problems of variability's like temperature, water cement ratio monitoring; compaction etc. The most challenging in bio concrete is to address issues of supplying the designated bacteria right in time \& proportion during mixing of concrete and practicability of handling the bacteria.

\section{Conclusion}

The $40 \%$ suspension in all the three cases has shown increased compressive strength as compared to $20 \%$ and $60 \%$. The compressive strength of CM 1:3 proportion showed an increase (CS) of $18 \% ; 12 \%$ for P. Fluorescence; B. Subtilis and decrease of $35 \%$ with B. Pumilis respectively. B. Subtilis with optimized $40 \%$ suspension having CFU $10 \times 10^{8} / \mathrm{ml}$ showed $4.32 \% ; 5.56 \%$; and $3.81 \%$ increase in CS of CC cubes with 3 days; 7 days and 28 days respectively, and $5.92 \%$ overall increase in CS of CC cubes as compared to the 3 days CS of control cube. Therefore it is concluded that B. Subtilis has shown its superiority in CS indicating it has produced more calcite to fill up the pores and give better bond between the ingredients of $\mathrm{CC}$.

\section{Acknowledgements}

We sincerely thank the funding received from KSCST. We also thank the HoD and faculty of Department of Biotechnology and Microbiology for providing facility of laboratory and helping in maintaining the cultures during the entire period of study. We also thank Dr. S B Vanakudre Dr. S G Joshi for their encouragement and support.

\section{References}

[1] M. S. Shetty, Concrete technology- Theory and practice, S. Chand Publications, $7^{\text {th }}$ Ed., 2013.

[2] F. Hammes \& W. Verstraete. Key roles of $\mathrm{pH}$ and calcium metabolism in microbial carbonate precipitation. Reviews in Environmental Science and Bio-Technology. vol.1, pp 3-7, 2002. https://doi.org/10.1023/A:1015135629155

[3] S. P. Reddy, M. V. Seshagiri Rao, P. Aparna \& C. Sasikala. Performance of standard grade bacterial Bacillus Subtilis concrete. Asian Journal of Civil Engineering (building and housing). vol.11. no.1, pp 43-55, 2010.

[4] S. Douglas \& T. J. Beveridge. Mineral formation by bacteria in natural microbial communities. FEMS Microbiology Ecology. vol 26. no.2, pp 79-88, 1998. https://doi.org/10.1111/j.1574-6941.1998.tbo0494.x
[5] M. Wu, B. Johannesson \& R. Mette. A review: Selfhealing in cementitious materials and engineered cementisious composite as a self-healing material. Construction and Building Materials. vol. 28, no.1, 2012.

https://doi.org/10.1016/j.conbuildmat.2011.08.086

[6] A. Talaiekhozan, A. Keyvanfar, A. Shafaghat, et al. Review of self-healing concrete research development, Bio Sucrets. Journal of Environmental Treatment Techniques, vol. 2, no.1, pp. 1-11, 2014.

[7] I. I. Muhammad, H. Afifudin \& H. Mohd Saman, "Bacillus subtilis - and thermos thermophilus - derived bio-concrete in enhancing concrete compressive strength. International Sustainability and Civil Engineering Journal. vol.1 no.1, pp 48 -56, 2012.

[8] P. Ghosh \& S. Mandal. Development of bio-concrete material using and enrichment culture of novel thermophilic anaerobic bacteria. Indian Journal of Experimental Biology. vol. 44, pp. 336-339, 2006.

[9] B. G. Jagadeesha Kumar, R. Prabhakara \& H. Pushpa. Effect of bacterial calcite precipitation on compressive strength of mortar cubes" International Journal of Engineering and Advanced Technology. vol. 2 no. 3, pp. 486-491, 2013.

[10] V. N. Kashyap \& V. Radhakrishna. A study on effect of bacteria on cement composites. International Journal of Research in Engineering and Technology. Conference Issue, 2013, pp. 356-360.

[11] P. Jagannathan, K. S. Satyanarayanan, A. D. Kantha, \& A. Satheshkumar. Studies on the mechanical properties of bacterial concrete with two bacterial species. Materials Today: Proceedings, vol. 5, no. 2, Part 3: pp. 8875-8879, 2018.

[12] W. D. Muynck, K. V. Tittelboom, N. W. De Belie \& W. Verstraete. Use of bacteria to repair CC. Cem. Concr. Res., vol. 40, pp. 157-166, 2010.

[13] W. D. Muynck, K. Cox, N. D. Belie \& W. Verstraete. Bacterial carbonate precipitation as alternative, surface treatment for concrete. Construction and Building Materials. vol. 22, pp. 875-885, 2008. https://doi.org/10.1016/j.conbuildmat.2006.12.011

[14] M. S. Vekariya \& J. Pitroda. Bacterial concrete: New era for construction industry. International Journal of Engineering Trends and Technology. vol. 4, no. 9, pp. 4128-4137, 2013.

[15] K. Vijay \& M. Murmu. Effect of calcium lactate on compressive strength and self-healing of cracks in microbial concrete. Front. Struct. Civ. Eng. vol. 13, pp. 515-525, 2019. https://doi.org/10.1007/s1 1709-018-0494-2

[16] S. K. Ramachandran, V. Ramakrishnan \& S. S. Bang. Remediation of concrete using micro-organisms. 
ACI Mater. J., vol. 98, pp. 3-9, 2001.

[17] V. Ramakrishnan, K. P. Ramesh \& S. S. Bang. Bacterial concrete. Proceedings of SPIE-International Society for Optical Engineering on Smart Materials, Australia, vol. 4234, pp. 168-176, 2001.

[18] M. V. Seshagiri Rao, V. Srinivasa Reddy, K. Achyutha Satya \& M. Azmatunnisa. A biological approach to enhance strength and durability in concrete structures. International Journal of Advances In Engineering E Technology. vol. 4, no 2, pp. 392-399, 2012.

[19] M. S. Vekariya \& J. Pitroda. Bacterial concrete: new era for construction industry. International Journal of Engineering Trends and Technology, vol. 4, no. 9, pp 4128-4137, 2013.

[20] S. Ghosh, M. Biswas, B. D. Chattopadhyay \& S. Mandal. Microbial activity on the microstructure of bacteria modified mortar. Cement and Concrete Composites. vol. 31, no. 2, pp 93-98, 2009.

[21] S. Stocks-Fischer, J. K. Galinath \& S. S. Bang. Microbiological precipitation of $\mathrm{CaCO}_{3}$. Soil Biology and Biochemistry. vol. 31, pp 1563-1571, 1999. https://doi.org/10.1016/So038-0717(99)00082-6

[22] V. Ramakrishnan, S. S. Bang, N. Srinivasan \& K. P. Ramesh. Durability of cement mortar made with different concentrations of bacteria. Proceedings of 25 International Conference of Cement Microscopy, Richmond, Virginia, April 2003.

[23] S. S. Bang, J. K. Galinath \& V. Ramakrishnan. Calcite precipitation induced by polyurethane immobilized Bacillus Pasteurii. Enzyme and Microbial Technology. vol. 28, pp. 404-409, 2001.

https://doi.org/10.1016/So141-0229(00)00348-3
[24] V. Ramakrishnan. Performance characteristics of bacterial concrete-a smart bio-material. In Proc. of the Ist. International Conference on Recent Advances in Concrete Technology, Washington, DC, pp. 67-78. 2007.

[25] H. A. Afifudin, W. B.Nadzarah, M.S. Hamidah \& H Noor Hana. Microbial participation in the formation of calcium silicate hydrated ( $\mathrm{CSH}$ ) from Bacillus Subtilis. The $2^{\text {nd }}$ International Building Control Conference, Procedia Engineering20, pp. 159-165, 2011. https://doi.org/10.1016/j.proeng.2011.11.151

[26] C. C. Gavimath, B. M. Mali, V. R. Hooli, J. D. Mallpur, A. B. Patil, D. P. Gaddi, C. R. Ternikar, \& B. E. Ravishankera. Potential application of bacteria to improve the strength of cement concrete published. International Journal of Advanced Biotechnology and Research, vol. 3, no.1, pp. 541-544, 2012.

[27] M. V. Seshagiri Rao, V. Srinivasa Reddy, D. Sreenivasa Rao \& C. H. Sasikala. Permeation properties of bacterial concrete, IOSR Journal of Mechanical and Civil Engineering. vol. 5, no. 6, pp. 8-12, 2013. https://doi.org/10.9790/1684-0560816

[28] M. Sridevi. Comparative study on the compressive strength of bacterial concrete using spirulina and Bacillus Subtilis. Recent Trends in Civil Engineering E Technology. vol. 8, no. 2, 2018.

[29] S. Arvind, S. Gandhimathi, R. Karthik, T. S. Madhumitha \& N. V. Manjunath. Study on compressive strength of bacterial concrete. International Journal of Intellectual Advancements and Research in Engineering Computations. vol. 5. no. 2, pp. 2531-2533, 2018.

[30] J. Michael, E. C. S. Chan, N. R. Krieg. Microbiology. Tata McGraw Hill, New Delhi, 1993.

\section{早}

CHITKARA UNIVERSITY

\section{Journal on Today's Ideas - Tomorrow's Technologies}

Chitkara University, Saraswati Kendra, SCO 160-161, Sector 9-C, Chandigarh, 160009, India

Volume -8, Issue-2 December 2020

ISSN 2321-3906

Copyright: [C 2020 Prakash Mallappa Munnoli et al.] This is an Open Access article published in Journal on Today’s Ideas - Tomorrow’s Technologies by Chitkara University, Publications. It is published with a Creative Commons Attribution- CC-BY 4.0 International License. This license permits unrestricted use, distribution, and reproduction in any medium, provided the original author and source are credited. 